\title{
Хірургічне лікування вираженої мітральної недостатності при пролапсі мітрального клапана
}

\author{
Мохнатий С. І., Довгань О. М. \\ ДУ «Науково-практичний медичний центр дитячої кардіології та кардіохірургії МОЗ України», \\ м. Київ, Україна
}

Резюме. У роботі представлено досвід ДУ «НПМЦДКК МОЗ України» в хірургічному лікуванні пацієнтів 3 мітральною недостатністю (МН), зумовленою пролапсом стулок мітрального клапана (МK).

Метою роботи є аналіз власного досвіду реконструктивних втручань на МК.

Матеріали і методи. Із січня 2011 до грудня 2017 року на базі ДУ «НПМЦДКК МОЗ України» прооперовано 146 пацієнтів з вираженою мітральною недостатністю, що зумовлена пролабуванням стулок мітрального клапана.

Результати. Корекція МК була остаточною у 144 (98,6 \%) пацієнтів. На момент виписування у 33 (23,9 \%) пацієнтів була відсутня залишкова МН. У 97 (66,4 \%) пацієнтів виявлена мінімальна (trivial) мітральна недостатність, у $15(10,3 \%)$ - невелика (mild) MH, а в $1(0,7 \%)$ - помірна (moderate) МН. Випадків вираженої МН на момент виписування не відзначалося. Таким чином, пластика мітрального клапана була успішною в 145 (99,3 \%) пацієнтів. Свобода від помірної та вираженої мітральної недостатності у віддалений післяопераційний період знизилась і становила 95,4%. Ми проаналізували 8 пацієнтів, які мали реоперації або прогресування залишкової МН. У всіх відзначали задовільний результат на момент виписування зі стаціонару, але незадовільний результат у віддалений період, причиною якого було використання штучних хорд та шовної анулоплікації.

Висновки.

1. Успішна пластика мітрального клапана можлива в більшості випадків вираженої мітральної недостатності, що зумовлена пролапсом МK.

2. Хороший безпосередній результат не означає збереження його у віддалений період.

3. Використання шовної анулоплікації є статистично достовірним фактором ризику прогресування мітральної недостатності в післяопераційний період.

4. Застосування резекції задньої стулки МК в комплексній реконструкції МК справляє позитивний вплив на прогноз пластики у віддалений період.

Ключові слова: пролапс мітрального клапана, мітральна недостатність, пластика мітрального клапана.

Патологія мітрального клапана (МK) дегенеративної етіології, до якої належить пролапс мітрального клапана (ПМК), є другою за поширеністю клапанною проблемою в Європейських країнах [1]. Хірургічне лікування мітральної недостатності (МН) довело свою ефективність у покращенні показників виживаності пацієнтів та зменшенні кількості клапанно-залежних ускладнень [2, 3]. Пластика МК демонструє кращі показники виживаності пацієнтів, збереження функції лівого шлуночка, а також зменшує вірогідність виникнення геморагічних або тромбоемболічних ускладнень у віддалений період порівняно з протезуванням MK [4]. Тому реконструктивні втручання на MK залишаються «золотим стандартом» у лікуванні пацієнтів з такою патологією. Незважаючи на хороші показники успішної пластики МК у ранній післяопераційний період, ряд авторів вказують на досить високий відсоток неуспішної корекції у віддалений період, що в $23 \%$ випадків потребує повторного хірургічного втручання [5].

Метою дослідження $є$ аналіз власного досвіду реконструктивних втручань на МК у пацієнтів з пролапсом мітрального клапана.

Матеріали і методи. Із січня 2011 до грудня 2017 року на базі ДУ «НПМЦДКК МОЗ України» прооперовано 146 пацієнтів з вираженою МН, що була зумовлена пролабуванням стулок МК. Середній вік пацієнтів у загальній групі становив 53,4 $\pm 15,1$ року (від 18 до 84 років). Серед пацієнтів досліджуваної групи більшість були чоловіки - 102 (69,9\%), жінок - 44 30,1\%). Усі пацієнти досліджуваної групи мали первинну МН дегенеративної природи і віднесені до II класу за функціональною класифікацією Карпентьє. Пацієнти з функціональною (ішемічною, вторинною) або змішаною природою МН були виключені з дослідження. Клінічна характеристика пацієнтів наведена в таблиці 1. 


\section{Таблиця 1}

Клінічна характеристика пацієнтів $(n=146)$

\begin{tabular}{lc} 
Стать, n (\%): & \\
- чоловіки & $102(69,9 \%)$ \\
- жінки & $44(30,1 \%)$ \\
\hline NYНА (функціональний клас), n (\%): & \\
I & $30(20,6 \%)$ \\
III & $65(44,5 \%)$ \\
IV & $47(32,2 \%)$ \\
\hline Пролапс стулок, n (\%): & $4(2,7 \%)$ \\
- передньої стулки & \\
- задньої стулки & $35(24,0 \%)$ \\
- обох стулок & $74(50,7 \%)$ \\
\hline Характеристика серцево-судинної системи: & $(25,3 \%)$ \\
- перенесений інфаркт міокарда, n (\%) & \\
- артеріальна гіпертензія, n (\%) & $5(3,4 \%)$ \\
- фібриляція передсердь, n (\%) & $78(53,4 \%)$ \\
- перенесені хірургічні втручання на Мк, n (\%) & $43(29,5 \%)$ \\
- тристулкова недостатність, n (\%): & $2(1,4 \%)$ \\
$\quad$ помірна & $48(32,9 \%)$ \\
$\quad$ виражена & $27(18,5 \%)$ \\
\hline Позасерцева супутня патологія, n (\%): & $14,4 \%)$ \\
- цукровий діабет & \\
- хронічні обструктивні захворювання легень & $8(5,5 \%)$ \\
- передопераційні порушення мозкового & $9(6,2 \%)$ \\
кровообігу & $9(6,2 \%)$ \\
&
\end{tabular}

Усі пацієнти були обстежені фізикально та ехокардіографічно. Для оцінювання МК використовували метод трансторакальної ЕхоКГ (ТТЕ) в поєднанні із черезстравохідною ЕхоКГ (ТЕЕ), що дозволило повноцінно візуалізувати всі сегменти МК. ТТЕ виконували апаратом PhilipsiE-33 з датчиком S5-1, a TEE - апаратом Philips Cx-50 з датчиком X7-2 (таблиця 2).

Діагноз ПМК встановлювали, якщо одна або обидві стулки МК мінімально на 2 мм виступали за межі кільця клапана при дослідженні по довгій осі. «Класичним» ПМК вважали випадки, коли було потовщення хоча б однієї стулки понад 5 мм.

На основі даних ЕхоКГ визначали анатомічні особливості МK, які пояснювали розвиток МН у конкретного пацієнта. В основі патогенезу ПМК лежить надлишок тканин стулок, пролабування того чи іншого сегмента стулки в порожнину лівого передсердя за рахунок розтягнення чи відриву хорд і розширення (анулодилятація) кільця MK. Подовження хорд ми спостерігали в 77 (52,7 \%) пацієнтів, у той час як відрив хорд виявили в $69(47,3 \%)$ випадках. Відрив хорд від задньої стулки відзначався набагато частіше $56(38,4 \%)$, ніж від передньої стулки -

\section{Таблиця 2}

Характеристика ехокардіографічних показників $(n=146)$

\begin{tabular}{lc} 
КДР ЛШ, см & $5,7 \pm 0,8$ \\
\hline КДО ЛШ, мл & $166 \pm 53,2$ \\
\hline КДІ ЛШ & $87 \pm 27,7$ \\
\hline КСР ЛШ, см & $3,9 \pm 0,6$ \\
\hline КСО ЛШ, мл & $70,3 \pm 28,7$ \\
\hline КСІ & $36,8 \pm 14,4$ \\
\hline Діаметр ПШ, см & $2,9 \pm 0,6$ \\
\hline Систолічний тиск ПШ, мм рт. ст. & $46,1 \pm 16,5$ \\
\hline Діаметр ЛП, см & $4,9 \pm 0,99$ \\
\hline Діаметр МК, см & $4,0 \pm 0,5$ \\
\hline VС (vena соntracta), мм & $9,2 \pm 2,1$ \\
\hline Фракція викиду, \% & $57,8 \pm 7,9$
\end{tabular}

Примітка. ЛШ - лівий шлуночок; ПШ - правий шлуночок; КДІ - кінцевий діастолічний індекс; КСР - кінцевий систолічний розмір; КСО - кінцевий систолічний об'єм; КСI - кінцевий систолічний індекс.

10 (6,8 \%) (рисунок 1). Патологічними переважно виявились хорди до сегмента Р2, відрив яких зафіксовано у $49(33,6 \%)$ пацієнтів. У $2(1,4 \%)$ пацієнтів був виявлений відрив хорд у ділянці комісур. Частіше відрив хорд зафіксовано в пацієнтів чоловічої статі - 55 (37,7 \%), у жінок ця патологія виявлена лише в 14 (9,6 \%) випадках.

Посегментне оцінювання клапана було вкрай важливим у передопераційному оцінюванні МK і визначенні плану хірургічного втручання. Хірургічному лікуванню підлягали всі пацієнти з вираженою МН.

Операцію виконували через серединний стернотомний доступ з використанням штучного кровообігу в умовах системної гіпотермії $\left(\mathrm{t}^{\circ} 28-32^{\circ} \mathrm{C}\right)$ та кардіоплегії. Апарат штучного кровообігу підключали шляхом канюляції аорти та обох порожнистих вен. Для за-

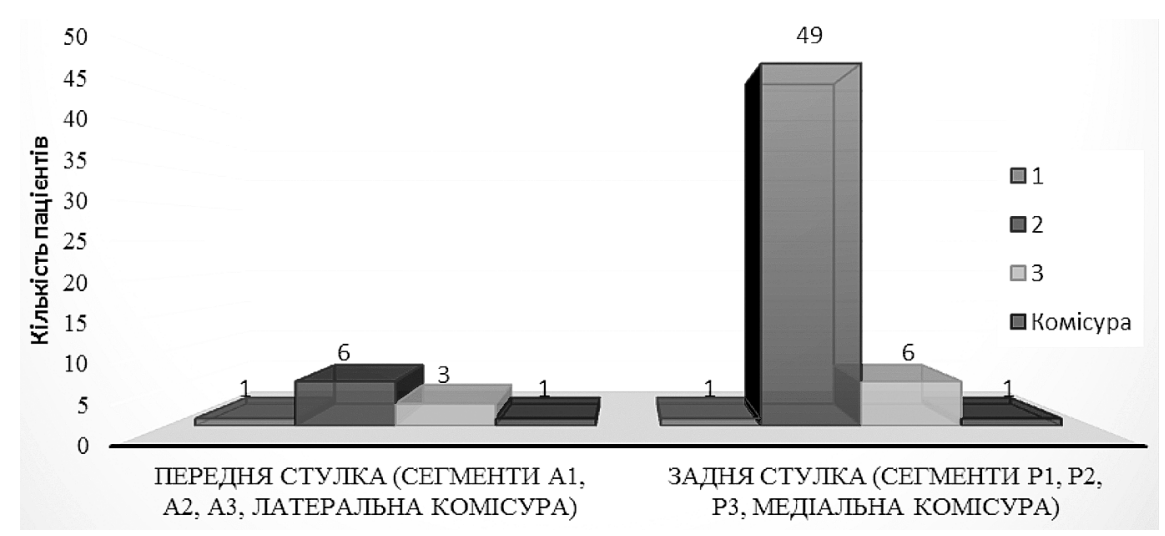

Рисунок 1. Посегментний аналіз відриву хорд МК 
хисту міокарда використовували антеградну гіперкаліємічну холодову кров'яну кардіоплегію, яку подавали в корінь аорти кожні 20-25 хв. Після перетискання аорти виконували доступ до МК. У переважній більшості випадків використали транссептальний доступ через праве передсердя та міжпередсердну перегородку 135 (92,5 \%). В 11 (7,5 \%) випадках застосували доступ через ліве передсердя. Ревізію клапана проводили за стандартною методикою [6].

Відповідно до анатомічних особливостей пролапсу визначали почерговість дій з відновлення компетентності МК. У першу чергу коригували анатомічні дефекти задньої стулки. Залежно від інтраопераційної картини проводили резекцію пролабуючого сегмента, нашивання штучних хорд або ушивання розщеплень між сегментами задньої стулки. Другою коригували передню стулку. Резекцію передньої стулки не проводили, тому основним методом корекції анатомії передньої стулки було нашивання штучних хорд до пролабуючих сегментів. Після корекції обох стулок проводили ревізію комісур клапана і за наявності патології їх ушивали. В останню чергу виконували анулоплікацію кільця МК. Компетентність мітрального клапана визначали за допомогою гідропроби, яку проводили методом наповнення порожнини лівого шлуночка ізотонічним розчином натрію хлориду й оцінювали зворотний потік на МК.

За потреби коригували залишкову МН шляхом ушивання розщеплень стулок, ушивання комісур МК або зшивання передньої та задньої стулок між собою

\section{Таблиця 3}

Використані хірургічні методики при реконструкції МК

$(n=146)$

Назва методики

Кількість (\%)

Анулоплікація:

- без анулоплікації

- шовна

- опірним кільцем:

$26 \mathrm{MM}$

$28 \mathrm{MM}$

$30 \mathrm{MM}$

$32 \mathrm{MM}$

$34 \mathrm{MM}$

$36 \mathrm{MM}$

$38 \mathrm{MM}$

$2(1,4 \%)$

$28(19,2 \%)$

$116(79,4 \%)$

тучні хорди

Резекція задньої стулки

- тріангулярна резекція

- квадріангулярна резекція

- слайдинг задньої стулки

1

8

12

28

31

22

14

Додаткове ушивання стулок:

- ушивання розщеплень стулок (cleft)

- ушивання в ділянці комісури

Пластика за Alfieri

(56,2\%)

$65(44,5 \%)$

$35(23,9 \%)$

$30(20,5 \%)$

$17,1 \%)$

$50(34,2 \%)$

$40(27,4 \%)$

$10(6,8 \%)$

$7(4,8 \%)$ за методикою Alfieri [7]. Операцію завершували типово [6]. Пацієнтам, у яких доопераційно була діагностована фібриляція передсердь, додатково проводили резекцію вушка лівого передсердя (ЛП). Ї̈̈ зазвичай виконували перед основним втручанням на МК. Рану ЛП ушивали дворядним швом (Prolene 4/0).

Загальна характеристика використаних методик реконструкції МК представлена в таблиці 3.

Двома найчастішими методиками, які використовували для відновлення компетентності МК, були резекція задньої стулки та формування штучних хорд. У 18 (12,3 \%) випадках ці дві методики поєднали. Додаткове ушивання розщеплень стулок знадобилось 50 (34,2 \%) пацієнтам. Пластика за Alfieri використана в 7 (4,8 \%) пацієнтів на ранніх етапах становлення реконструктивних операцій на МК у нашому центрі. Цю методику застосовували лише за неможливості досягнення компетентності МК іншим способом, як альтернатива протезуванню.

Залежно від анатомічної характеристики МK всі пацієнти були розподілені на 3 групи. Ізольований пролапс передньої стулки відзначали у 35 (23,9 \%) пацієнтів, ізольований пролапс задньої стулки - у 74 (50,7 \%), пролапс обох стулок MK - у 37 (25,4 \%) пацієнтів (таблиця 4).

Як бачимо з таблиці 4, кожна анатомічна група пролапсу МK характеризувалась різним співвідношенням використаних хірургічних методик. Метод формування штучних хорд переважав при ізольованому пролапсі передньої стулки і був основною методикою реконструкції для цього виду пролапсу. Для ізольованого пролапсу задньої стулки резекцію стулки використовували частіше, ніж методику штучних хорд. При пролапсі передньої стулки резекцію взагалі не виконували. Для двостулкового пролапсу характерне застосування обох основних методик майже в однако-

\section{Таблиця 4}

Застосовані методики реконструкції МК залежно від анатомічної характеристики пролапсу $\mathrm{MK}(n=146)$

\begin{tabular}{lccc} 
Назва & $\begin{array}{c}\text { Ізольований } \\
\text { пролапс } \\
\text { мередньої } \\
\text { стулки, } \mathbf{n}=35\end{array}$ & $\begin{array}{c}\text { Ізольований } \\
\text { пролапс } \\
\text { задньої } \\
\text { стулки, } \\
\mathbf{n = 7 4}\end{array}$ & $\begin{array}{c}\text { Двостулковий } \\
\text { пролапс, } \\
\mathbf{n}=37\end{array}$ \\
\hline Штучні хорди & $30(85,7 \%)$ & $27(36,5 \%)$ & $25(67,6 \%)$ \\
\hline $\begin{array}{l}\text { Резекція } \\
\text { стулки }\end{array}$ & 0 & $42(56,8 \%)$ & $23(62,2 \%)$ \\
\hline $\begin{array}{l}\text { Ушивання } \\
\text { розщеплень }\end{array}$ & $2(5,7 \%)$ & $20(27 \%)$ & $18(48,6 \%)$ \\
\hline $\begin{array}{l}\text { Ушивання } \\
\text { комісури }\end{array}$ & $4(11,4 \%)$ & $1(1,4 \%)$ & $5(13,5 \%)$ \\
\hline $\begin{array}{l}\text { Пластика за } \\
\text { Аlfіегі }\end{array}$ & $2(5,7 \%)$ & $3(4,1 \%)$ & $2(5,4 \%)$
\end{tabular}


вій кількості випадків, а також частіше використання методики ушивання розшеплень порівняно з іншими анатомічними варіантами пролапсу МК.

У переважної більшості пацієнтів - 144 (98,6 \%) виконано анулоплікацію МК. У 28 (19,2 \%) випадках застосована шовна анулоплікація, у той час як у 116 (79,4 \%) пацієнтів - імплантація опірних мітральних кілець. У 2 (1,4 \%) пацієнтів анулоплікацію не виконували. Обидва пацієнта були з ішемічною хворобою серця, де ПМК був супутньою патологією і корекція МН полягала в зшиванні передньої та задньої стулок у сегментах A2-P2 «край до краю» за Alfieri.

Для анулоплікації опірним кільцем у 61 (53,9\%) випадку використані опірні кільця CarpentierEdwards Physio (Edwards LifeSciences, Irvine, CA, USA), y 37 (32,7 \%) - Medtronic CG Future (Medtronic, Minneapolis, MN, USA), y 16 (14,1\%) - SJM Seguin (St. Jude MedicalInc, St. Paul, MN, USA), в 1 (0,9\%) пацієнта анулопластика виконана кільцем Medtronic Profile 3D (Medtronic, Minneapolis, MN, USA), ще в $1(0,9 \%)$ випадку - Sorin Sovering (Sorin Group, Italy). Для проміжних розрахунків та первинної підготовки таблиць використовувався пакет Microsoft Office Excel. Основну частину математичної обробки даних виконували на персональному комп'ютері з використанням стандартних статистичних пакетів STATISTICA 10.0 portable.

Результати та обговорення. Корекція МК була остаточною у $144(98,6 \%)$ пацієнтів. У $2(1,4 \%)$ пацієнтів після завершення основного етапу операції при плановому обстеженні на ТЕЕ виявлений незадовільний результат, який потребував повторного запуску штучного кровообігу й додаткової корекції МН. В одного пацієнта за даними ТЕЕ виявили обструкцію вихідного тракта лівого шлуночка передньою стулкою MK (Systolic Anterior Motion - SAM), що потребувало додаткової резекції задньої стулки, висота якої була більшою за 15 мм. У другому випадку діагностовано помірну МН, причиною якої була надмірна відстань (більше 5 мм) між нашитими до задньої стулки штучними хордами, що призвело до залишкового пролабування стулки в цій ділянці. Мітральну недостатність усунули нашиванням додаткових штучних хорд до пролабуючої частини задньої стулки.

Середній час штучного кровообігу під час корекції МН становив $154 \pm 44$ хв, середній час перетискання аорти - $103 \pm 32$ хв. Тривалість штучної вентиляції сягала в середньому $6,7 \pm 4,5$ год. Середній час перебування в реанімаційному відділенні - 2,3 доби. У ранній післяопераційний період летальних випадків не відзначалося. У 2 (1,4 \%) пацієнтів були ускладнення у вигляді гострого порушення мозкового кровообігу із залишковим неврологічним дефіцитом на момент виписування. Післяопераційні кровотечі, які потребували рестернотомії, спостерігалися у 7 (4,8 \%) пацієнтів.

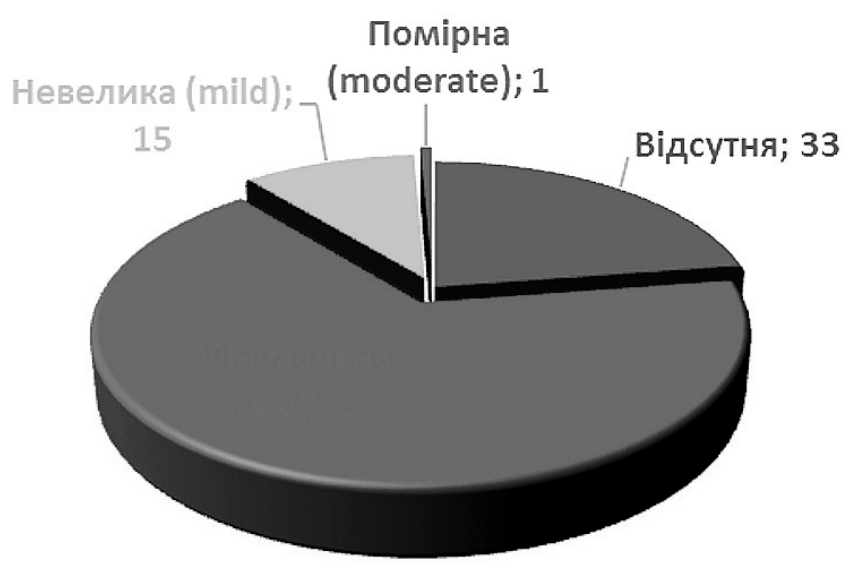

Рисунок 2. Залишкова МН на момент виписування $(n=146)$

На момент виписування у 33 (23,9\%) пацієнтів була відсутня залишкова МН. У 97 (66,4 \%) пацієнтів виявлена мінімальна (trivial) MH, у $15(10,3 \%)$ - невелика (mild) $\mathrm{MH}$, а в $1(0,7 \%)$ - помірна (moderate) МН (рисунок 2). Випадків вираженої МН на момент виписування не зафіксовано. Таким чином, пластика МК була успішною в 145 (99,3\%) пацієнтів.

Усі прооперовані пацієнти були обстежені в ранній післяопераційний період, у терміні 6 і 12 місяців. У подальшому обстеження проводили з періодичністю в 12 місяців. Середній післяопераційний термін спостереження становив $39,7 \pm 19$ міс. (мінімальний -14 , максимальний -83 міс.).

У ранній післяопераційний період 3 (2,1 \%) пацієнтів були прооперовані повторно у зв'язку з прогресуванням залишкової МН. У 2 випадках виконане протезування механічним протезом через 3 і 9 місяців після первинної операції. Причиною прогресування МН була неспроможність шовної анулоплікації в одного пацієнта 3 двостулковим ПМК та прогресування пролапсу передньої стулки в другого пацієнта. Третій пацієнт був повторно прооперований через 8 місяців після первинної пластики МК у зв'язку з появою скарг на задишку під час фізичного навантаження внаслідок прогресування МН до помірної. Причиною МН був збільшений у розмірах сегмент Р2 задньої стулки. Цьому пацієнту виконали повторну пластику МK, у ході якої пролабуючий сегмент додатково фіксували двома штучними хордами.

Таким чином, свобода від реоперації, як і свобода від помірної та вираженої МН в ранній післяопераційний період становила 97,9\% (143 із 146 пацієнтів).

Серед прооперованих 146 пацієнтів у віддалений період були отримані відомості про 134 (91,8 \%) пацієнтів. 312 пацієнтами втрачено зв'язок. Загальна летальність досягла $1,4 \%$ - померли 2 пацієнта. Один з них помер через 18 місяців після первинної операції 


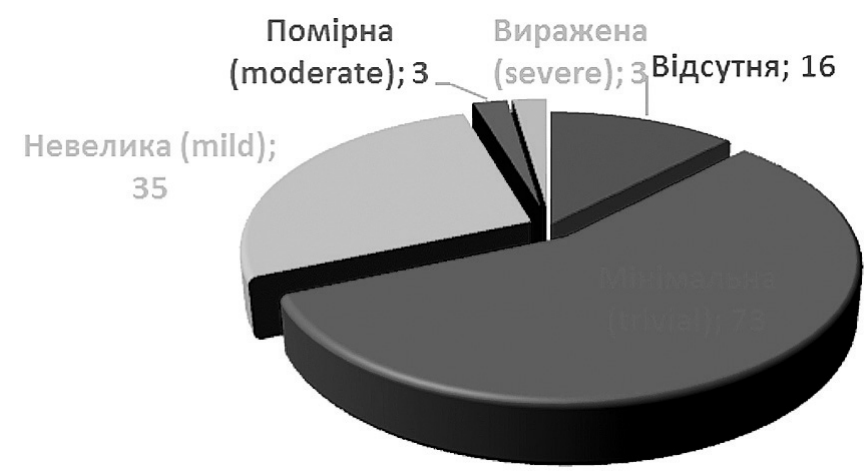

Рисунок 3. Залишкова МН у віддалений період ( $n=130)$

внаслідок хронічної серцевої недостатності на фоні ішемічної хвороби серця. Другий - через 24 місяці внаслідок розвитку ускладнень цирозу печінки, який був діагностований до первинної операції. Загальна характеристика залишкової МН серед решти 130 пацієнтів (за виключенням померлих і пацієнтів з протезуванням МК) відображена на рисунку 3. У 16 (12,3 \%) пацієнтів була відсутня залишкова МН. У 73 (56,2 \%) пацієнтів виявлена мінімальна (trivial) $\mathrm{MH}$, у 35 (26,9 \%) - невелика (mild) $\mathrm{MH}$, у 3 (2,3\%) - помірна (moderate) $\mathrm{MH}$ і в $3(2,3 \%)$ пацієнтів - виражена МН.

Таким чином, свобода від помірної та вираженої МН у віддалений післяопераційний період знизилась і становила 95,4\%. Проаналізувавши 8 (5,5\%) із 146 пацієнтів, які мали реоперації або прогресування МН, ми отримали такі дані. Усі 8 пацієнтів мали задовільний результат на момент виписування із стаціонару. У 33 них була відсутня або мінімальна (trivial) $\mathrm{MH}$, у решти ने 5- невелика (mild) МН. У 7 з них основним методом корекції МН було нашивання штучних хорд у процесі реконструкції МК, що вказує на залежність результату цієї методики від досвіду хірурга. У 2 з 8 пацієнтів було використано шовну анулоплікацію, яка, очевидно, недостатньо ефективна для стабілізації кільця МК і не забезпечує адекватного віддаленого результату операціï. 3 точки зору анатомічної характеристики пролапсу MK, незадовільні результати траплялись в усіх трьох групах: при ізольованому пролапсі передньої стулки у 3 пацієнтів, при ізольваному пролапсі задньої стулки - у 3 і при двостулковому пролапсі - у 2 пацієнтів. Але якщо порахувати відсоткову частку цих пацієнтів у межах кожної з груп, то вийде, що найгірший результат пластики в пацієнтів з ізольованим пролапсом передньої стулки (3 $(8,6 \%)$ з 35), дещо менший відсоток неуспіху в пацієнтів з двостулковим пролапсом МК (2 $(5,4 \%)$ з 37) і найменша кількість незадовільних результатів при ізольованому пролапсі задньої стулки (3 (4,1\%) з 74 пацієнтів).
За допомогою кореляційного аналізу з використанням таблиць спряженості, коефіцієнту кореляції Спірмена та коефіцієнту спряженості Пірсона було достовірно встановлено, що використання шовної анулоплікації є фактором ризику неуспішної пластики МК у віддалеий період порівняно з анулоплікацією опірними кільцями $\left(\mathrm{RR}=3,9 ; \chi^{2}=0,002 ; \mathrm{rS}=0,002\right)$. Також було встановлено, що використання резекції задньої стулки покращує результат пластики МK $\left(\mathrm{RR}=2,1 ; \chi^{2}=0,049 ; \mathrm{rS}=0,05\right)$.

\section{Висновки}

1. Успішна пластика МК можлива в більшості випадків вираженої МН, що зумовлена пролапсом МК.

2. Хороший безпосередній результат не означає збереження його у віддалений період.

3. Використання шовної анулоплікації є статистично достовірним фактором ризику прогресування МН у післяопераційний період.

4. Застосування резекції задньої стулки МК у комплексній реконструкції МК справляє позитивний вплив на прогноз пластики у віддалений період.

\section{Список використаних джерел \\ References}

1. Iung B, Baron G, Butchart EG, Delahaye F, GohlkeBдrwolf C, Levang OW, et al. A prospective survey of patients with valvular heart disease in Europe: the Euro Heart Survey on Valvular Heart Disease. Eur. Heart J. 2003;24:1231-43. https://doi.org/10.1016/S0195-668X(03)00201-X

2. David TE, Armstrong S, McCrindle BW, Manlhiot C. Late outcomes of mitral valve repair for mitral regurgitation due to degenerative disease. Circulation. 2013 Apr;127(14):1485-92. https://doi.org/10.1161/ CIRCULATIONAHA.112.000699

3. Nishimura RA, Otto CM, Bonow RO. Guideline for the management of patients with valvular heart disease: a report of the American College of Cardiology/American Heart Association Task Force on Practice Guidelines. Circulation. 2014;129:521-643.

4. Lazam S, Vanoverschelde JL, Tribouilloy C, Grigioni F, Suri RM, Avierinos JF, et al. Twenty-year outcome after mitral repair versus replacement for severe degenerative mitral regurgitation: analysis of a large, prospective, multicenter, international registry. Circulation. 2017 Jan 31;135(5):410-22. https://doi.org/10.1161/ CIRCULATIONAHA.116.023340

5. Nishida H, Fukui T, Kasegawa H, Kin H, Yamazaki M, Takanashi S. Causes of repair failure for degenerative mitral valve disease and reoperation outcomes. Eur $\mathbf{J}$ Cardiothorac Surg. 2018 Jun 1;53(6):1244-50. https://doi. org/10.1161/10.1093/ejcts/ezx468

6. Мохнатий СI, Підгайна ЛВ, Бабляк ОД, Довгань ОМ. Безпосередні результати хірургічного лікування пролапсу мітрального клапана за його недостатності. Клінічна хірургія. 2016;11:29-32.

Mokhnatyi SI, Pidgayna LV, Bablyak OD, Dovgahn OM. 
[Immediate Results of Surgical Treatment of a Mitral Valve Prolapse in its Insufficiency]. Klinichna khirurhiia. 2016;11:29-32. (in Ukrainian).
7. Pozzoli A, Vicentini L, De Bonis M, Di Giannuario G, La Canna G, Alfieri O. Contemporary application of the edgeto-edge repair. Ann Cardiothorac Surg. 2015 Jul;4(4):376-9. https://doi.org/10.3978/j.issn.2225-319X.2014.12.02

\title{
Surgical Treatment of Severe Mitral Insufficiency in Patients with Mitral Valve Prolapse
}

\author{
Mokhnatyi S. I., Dovgan O. M. \\ Ukrainian Children's Cardiac Center, Kyiv, Ukraine
}

\section{Abstract}

In this paper we represent the experience of the UCCC of the Ministry of Health of Ukraine in the surgical treatment of patients with mitral insufficiency caused by the prolapse of the mitral valve (MV) cusps.

The aim. To analyze our own experience in reconstructive interventions on MV in patients with mitral valve prolapse.

Materials and methods. From January 2011 to December 2017, 146 patients with severe mitral insufficiency underwent surgical interventions on the basis of the UCCC due to the prolapse of the mitral valve cusps.

Results. MV repair was final in 144 (98.6\%) patients. At the time of discharge, $33(23.9 \%)$ patients had no residual MV insufficiency. Minimum (trivial) MV insufficiency was found in 97 (66.4\%) patients, mild MV insufficiency in 15 (10.3\%), and moderate in $1(0.7 \%)$ patient. There were no patients with severe MV insufficiency at the time of discharge. Therefore, mitral valve repair was successful in 145 (99.3\%) patients. Freedom from moderate and severe MV insufficiency in the remote postoperative period decreased and amounted to $95.4 \%$. We analyzed 8 patients who had reoperation or showed progression of residual mitral insufficiency. All of them had satisfactory result at the time of discharge from the hospital, but had unsatisfactory result at the follow-up. The reason for the unsatisfactory result was the use of artificial chords and suture annuloplication.

Conclusion. Successful mitral valve repair is possible in most cases of severe mitral valve regurgitation caused by MV prolapse. A good immediate postoperative result does not mean long-term valve competency. Suture annuloplasty is a strong risk factor for the progression of MV insufficiency in the postoperative period. Resection of the posterior cusp in complex MV repair has positive impact on the long-term prognosis.

Keywords: mitral valve prolapse, mitral insufficiency, mitral valve repair.

Стаття надійшла в редакцію 16.04.2019 р. 